Ekspansi: Jurnal Ekonomi, Keuangan, Perbankan dan Akuntansi

ISSN (Online): 2580-7668 ISSN (Print): 2085-5230

Vol. 12, No. 1 (Mei 2020), Hal. 133 - 148

\title{
PENGARUH PEMBIAYAAN DENGAN PRINSIP JUAL BELI DAN PEMBIAYAAN DENGAN PRINSIP BAGI HASIL TERHADAP PERFORMA BISNIS PT BANK BRI SYARIAH
}

\author{
Widya Sari ${ }^{1}$ \\ ${ }^{1}$ Universitas Ma'soem, Bandung, Indonesia \\ Email Korespondensi: widya.sari.sy@gmail.com
}

\begin{abstract}
There are many things that affect a company's business performance. This study tries to relate the effect of financing by buying and selling, and profit-loss sharing financing, on business performance at PT Bank BRI Syariah (BRIS), which is proxied by return on assets. The results of this study show that the murabahah financing and the musharakah financing, partially, have a significant effect on return on assets. While mudharabah financing, partially, do not have a significant effect on return on assets. The results also obtained that the existence of a strong relationship between independent variables simultaneously with the dependent variable. It is also proved by the F-test results, that the effect of financing by buying and selling, and profit-loss sharing financing, have a strong influence on business performance at BRIS, if it correlated together.
\end{abstract}

Keywords: financing, buy-sell principle, profit-loss sharing, ROA

Abstrak: Terdapat banyak hal yang mempengaruhi performa bisnis suatu perusahaan. Penelitian ini mencoba mengaitkan pengaruh pembiayaan dengan prinsip jual beli dan pembiayaan dengan prinsip bagi hasil terhadap performa bisnis di PT Bank BRI Syariah (BRIS) , yang dicerminkan oleh return on asset. Berdasarkan hasil penelitian ini, membuktikan bahwa keuntungan pembiayaan murabahah dan keuntungan pembiayaan musyarakah, secara parsial memiliki pengaruh signifikan terhadap return on asset di BRIS. Sedangkan keuntungan pembiayaan mudharabah, secara parsial tidak memiliki pengaruh signifikan terhadap return on asset di BRIS. Didapatkan juga hasil bahwa pengaruh variabel independent yaitu keuntungan pembiayaan dengan prinsip jual beli dan keuntungan pembiayaan dengan prinsip bagi hasil, secara simultan, terhadap variabel dependent yaitu return on asset di BRIS terdapat pengaruh signifikan, yaitu sebesar 52,8\%. Sedangkan dari hasil uji-F, dapat dibuktikan bahwa pengaruh pembiayaan dengan prinsip jual beli dan pembiayaan dengan prinsip bagi hasil, memiliki pengaruh kuat terhadap performa bisnis di BRIS, jika berkorelasi bersama.

Kata Kunci: Pembiayaan, Prinsip Jual Beli, Prinsip Bagi Hasil, ROA 


\section{PENDAHULUAN}

Saat ini perbankan syariah masih merupakan salah satu sektor yang semakin berkembang dengan pesat. Bank syariah berfungsi memberikan kemudahan terhadap aktivitas investasi dan aktivitas jual beli, serta melakukan pelayanan jasa simpanan ataupun jasa perbankan bagi para nasabah di dalam sektor riil, (Ascarya, 2013). Keberadaan bank syariah diharapkan dapat mendorong dan mempercepat kemakmuran ekonomi masyarakat melalui kegiatan perbankan, termasuk pembiayaan dan investasi yang sesuai kaidah Islam.

Banyaknya pilihan bank syariah bagi nasabah, secara langsung ataupun tidak langsung, memiliki pengaruh terhadap pencapaian profitabilitas bank syariah. Meskipun bank syariah berorientasi lebih daripada sekedar menjalankan usaha, namun keamampuan bank syariah dalam menghasilkan profit tetap menjadi indikator penting mengenai keberlanjutan entitas bisnis.

Untuk dapat membantu memacu kemajuan usaha ekonomi, bank syariah perlu meningkatkan kinerjanya agar semakin lebih baik. Purwoko dan Sudiyatno (2013) mengemukakan bahwa salah satu faktor yang mempengaruhi kinerja keuangan bank yaitu bagaiamana suatu bank mengelola asetnya. Pengelolaan aset pada bank syariah antara lain dilakukan melalui penyaluran pembiayaan.

Karim (2014) menguraikan tentang pembiayaan yang merupakan bentuk penyaluran dana yang dilakukan bank syariah. Terdapat empat pola prinsip pembiayaan yang dimiliki bank syariah yaitu prinsip jual beli, prinsip bagi hasil, prinsip ujroh dan akad pelengkap. Di antara beberapa pola prinsip pembiayaan tersebut, terdapat dua prinsip yang paling umum dilakukan oleh bank syariah, yakni prinsip jual beli dan prinsip bagi hasil.

Banyaknya keuntungan yang diterima dari pembiayaan yang disalurkan, menentukan pendapatan bank syariah. Pada pembiayaan dengan prinsip jual beli, keuntungan yang diterima berasal dari mark up yang ditentukan berdasarkan kesepakatan antara bank dengan nasabah. Sedangkan keuntungan dari prinsip bagi hasil ditentukan berdasarkan kesepakatan besarnya nisbah, yang pada akhirnya keuntungan bank dipengaruhi oleh pengakuan penghasilan usaha yang diperoleh nasabah yang mendapatkan fasilitas pembiayaan.

Harahap dan rekan (2010), sebagaimana dikutip oleh Rahman dan Rochmanika (2011), menyebutkan bahwa akad yang banyak digunakan dalam pembiayaan pada prinsip jual beli adalah murabahah, salam dan istishna'. Sedangkan pada prinsip bagi hasil, akad yang banyak digunakan adalah mudharabah dan musyarakah. Statistik Perbankan Syariah yang dirilis oleh Otoritas Jasa Keuangan, juga memaparkan fakta bahwa, akad murabahah mendominasi pembiayaan yang disalurkan bank syariah dan disusul dengan akad mudharabah dan musyarakah. 


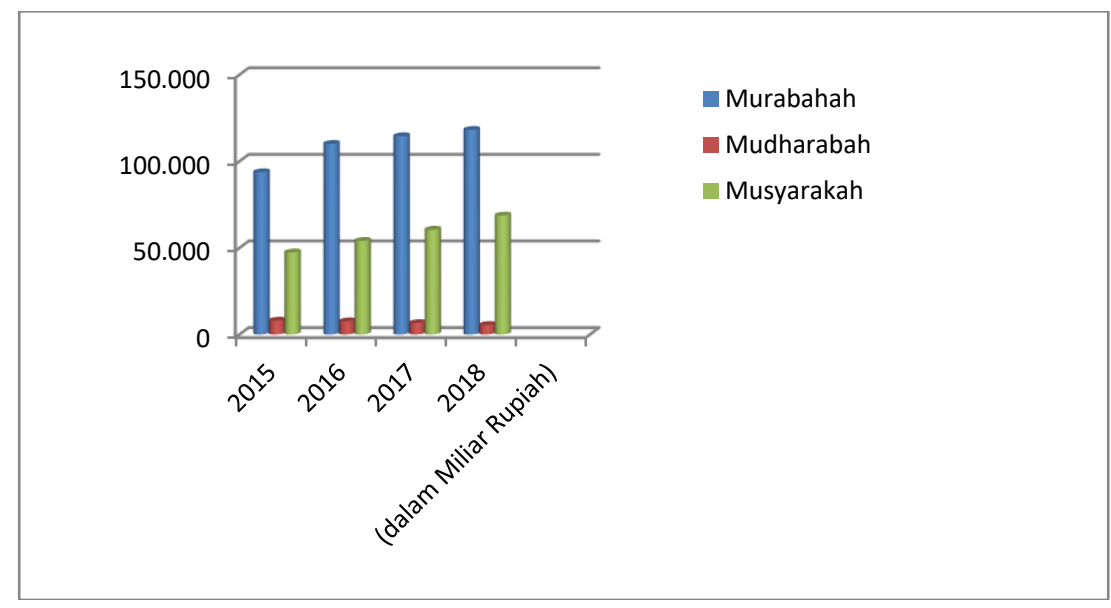

Sumber : Otoritas Jasa Keuangan (2019)

\section{Gambar 1. Pembiayaan Berdasarkan Jenis Akad - Bank Umum Syariah di Indonesia}

Perolehan pendapatan dari pembiayaan yang disalurkan, akan memperbaiki tingkat profitabilitas bank, yang tercermin dari perolehan laba yang meningkat, (Firdaus, 2011). Tingkat profitabilitas merupakan salah satu indikator yang digunakan untuk mengukur kinerja suatu bank, yang berarti juga mencerminkan performa bisnis bank tersebut. Salah satu rasio profitabilitas yang cukup banyak digunakan untuk menilai kinerja suatu bank adalah Return on Asset (ROA). ROA juga sering digunakan untuk membandingkan performa bisnis perusahaan dibandingkan dengan kompetitor dan industri sejenis (Gitman, 2014).

Berikut ini adalah data-data terkait keuntungan pembiayaan murabahah, keuntungan bagi hasil pembiayaan mudharabah, dan keuntungan bagi hasil pembiayaan musyarakah serta return on asset (ROA) di PT. BANK BRI Syariah periode 2014-2018.

Tabel 1. Perkembangan Keuntungan Pembiayaan Murabahah, Mudharabah, dan Musyarakah PT. Bank BRI Syariah Periode 2014-2018 (dalam Jutaan Rupiah)

\begin{tabular}{|c|c|c|c|}
\hline \multirow{3}{*}{ Tahun } & $\begin{array}{c}\text { Keuntungan } \\
\text { Pembiayaan } \\
\text { Murabahah }\end{array}$ & $\begin{array}{c}\text { Keuntungan } \\
\text { Pembiayaan } \\
\text { Mudharabah }\end{array}$ & $\begin{array}{c}\text { Keuntungan } \\
\text { Pembiayaan } \\
\text { Musyarakah }\end{array}$ \\
\hline \multirow{4}{*}{2014} & 340.296 & 27.245 & 86.081 \\
\cline { 2 - 4 } & 669.754 & 53.239 & 173.131 \\
\cline { 2 - 4 } & 1.020 .236 & 81.375 & 271.700 \\
\cline { 2 - 4 } & 1.335 .164 & 115.656 & 385.948 \\
\hline \multirow{4}{*}{2015} & 378.325 & 26.809 & 120.894 \\
\cline { 2 - 4 } & 739.386 & 59.776 & 245.160 \\
\cline { 2 - 4 } & 1.098 .634 & 93.429 & 376.787 \\
\cline { 2 - 4 } & 1.458 .382 & 128.509 & 513.496 \\
\hline \multirow{3}{*}{2016} & 373.053 & 38.329 & 131.786 \\
\cline { 2 - 4 } & 764.695 & 79.399 & 264.322 \\
\cline { 2 - 4 } & 1.165 .416 & 123.450 & 393.160 \\
\hline
\end{tabular}




\begin{tabular}{|c|c|c|c|}
\hline \multirow{3}{*}{ Tahun } & $\begin{array}{c}\text { Keuntungan } \\
\text { Pembiayaan } \\
\text { Murabahah }\end{array}$ & $\begin{array}{c}\text { Keuntungan } \\
\text { Pembiayaan } \\
\text { Mudharabah }\end{array}$ & $\begin{array}{c}\text { Keuntungan } \\
\text { Pembiayaan } \\
\text { Musyarakah }\end{array}$ \\
\hline \multirow{4}{*}{2017} & 1.533 .338 & 167.105 & 526.506 \\
\hline \multirow{4}{*}{2018} & 375.632 & 40.885 & 128.160 \\
\cline { 2 - 4 } & 747.866 & 78.648 & 255.403 \\
\cline { 2 - 4 } & 1.117 .496 & 112.431 & 391.847 \\
\cline { 2 - 4 } & 1.507 .099 & 141.919 & 528.286 \\
\hline \multirow{3}{*}{} & 363.988 & 25.380 & 138.749 \\
\cline { 2 - 4 } & 716.799 & 47.197 & 289.940 \\
\cline { 2 - 4 } & 1.088 .217 & 67.457 & 463.604 \\
\hline
\end{tabular}

Sumber : BRI Syariah (2019)

Dari data yang diperoleh, terlihat pembiayaan murabahah menjadi pembiayaan yang sangat diminati oleh nasabah PT Bank BRI Syariah, terlihat dari tahun ke tahun jumlah keuntungan pembiayaannya semakin bertambah. Jumlah keuntungan pembiayaan murabahah pada tahun 2014 sebesar Rp. 1.335 .164 (dalam jutaan) dan meningkat menjadi sebesar Rp. 1.480 .934 (dalam jutaan) pada tahun 2018.

Pembiayaan lain yang cukup menarik minat nasabah adalah pembiayaan musyarakah, yang merupakan akad dengan prinsip bagi hasil. Dari data laporan keuangan terlihat jumlah keuntungan pembiayaan ini, pada tahun 2014 sebesar Rp. 385.948 (dalam jutaan) dan meningkat pesat menjadi sebesar Rp. 640.468 (dalam jutaan) pada tahun 2018. Sehingga peneliti berasumsi bahwa perolehan tersebut memberikan suatu kontribusi yang besar terhadap rasio keuangan bank yang terkait profitabilitas bank yakni return on asset bank.

Pembiayaan mudharabah menempati urutan ketiga dalam pembiayaan yang dipilih nasabah PT Bank BRI Syariah. Namun terdapat kejanggalan, yang terlihat dari data laporan keuangan, yaitu adanya penurunan jumlah keuntungan bagi hasil pembiayaan mudharabah yang cukup besar. Jika pada tahun 2014 sebesar Rp. 115.656 (dalam jutaan), dan meningkat pada tahun 2015 dan 2016. Namun keuntungan pembiayaan tersebut mengalami penurunan pada tahun 2017 dan semakin menurun di tahun 2018, hingga hanya dapat mencapai angka Rp. 84.102 (dalam jutaan). Dengan memperhatikan terjadinya penurunan tersebut, peneliti mengasumsikan terdapat juga pengaruhnya terhadap rasio keuangan bank yang terkait profitabilitas bank yakni return on asset PT Bank BRI Syariah.

Tabel 2. Perkembangan Return On Asset PT. Bank BRI Syariah Periode 20142018

(dalam Persentase)

\begin{tabular}{|c|c|c|}
\hline Tahun & Triwulan & ROA \\
\hline \multirow{3}{*}{2014} & I & 0,46 \\
\cline { 2 - 3 } & II & 0,03 \\
\cline { 2 - 3 } & III & 0,20 \\
\hline
\end{tabular}




\begin{tabular}{|c|c|c|}
\hline Tahun & Triwulan & ROA \\
\hline & IV & 0,08 \\
\hline \multirow{4}{*}{2015} & I & 0,53 \\
\cline { 2 - 3 } & II & 0,78 \\
\cline { 2 - 3 } & III & 0,80 \\
\cline { 2 - 3 } & IV & 0,76 \\
\hline \multirow{4}{*}{2016} & I & 0,99 \\
\cline { 2 - 3 } & II & 1,03 \\
\cline { 2 - 3 } & III & 0,98 \\
\cline { 2 - 3 } & IV & 0,95 \\
\hline \multirow{4}{*}{2017} & I & 0,65 \\
\cline { 2 - 3 } & II & 0.71 \\
\cline { 2 - 3 } & III & 0.82 \\
\cline { 2 - 3 } & IV & 0,51 \\
\hline \multirow{4}{*}{2018} & I & 0,86 \\
\cline { 2 - 3 } & II & 0,92 \\
\cline { 2 - 3 } & III & 0,77 \\
\cline { 2 - 3 } & IV & 0,43 \\
\hline
\end{tabular}

Sumber : BRI Syariah (2019)

Berdasarkan uraian di atas, peneliti tertarik melakukan penelitian untuk memperlihatkan pengaruh pembiayaan dengan prinsip jual beli dan pembiayaan dengan prinsip bagi hasil terhadap performa bisnis PT Bank BRI Syariah.

\section{TINJAUAN PUSTAKA}

\subsection{Pembiayaan dan Keuntungan Pembiayaan}

Bank syariah, dalam operasionalnya, menyalurkan dana dalam bentuk pembiayaan-pembiayaan, atau istilah teknisnya aktiva produktif. Menurut ketentuan Bank Indonesia, sebagaimana dikutip oleh Muhammad (2014 : 302), pembiayaan adalah penanaman dana Bank Syariah, baik dalam rupiah maupun valuta asing, kepada pihak lain atau nasabah bank tersebut.

Di dalam Undang-Undang No. 10 Tahun 1998, disebutkan definisi pembiayaan berdasarkan prinsip syariah adalah penyediaan uang atau tagihan yang dipersamakan dengan itu berdasarkan persetujuan atau kesepakatan antara bank dengan pihak lain yang mewajibkan pihak yang dibiayai untuk mengembalikan uang atau tagihan tersebut setelah jangka waktu tertentu dengan imbalan atau bagi hasil.

Terkait dengan pembiayaan, maka bagi hasil yang dimaksud dalam definisi tersebut mengacu pada pembagian keuntungan, atau kerugian, yang terjadi antara bank dengan nasabah penerima dana pembiayaan. Menurut Muhammad (2014 : 26), bagi hasil merupakan distribusi beberapa bagian laba dari suatu perusahaan. Bentukbentuk distribusi ini berupa pembagian laba akhir, bonus pada para pegawai, serta pembagian keuntungan yang terjadi antara bank dengan nasabah penyimpan dana, maupun antara bank dengan nasabah penerima dana. 


\subsection{Pembiayaan Murabahah dan Keuntungan Murabahah}

Di dalam Fatwa Dewan Syari'ah Nasional No.: 04/DSN-MUI/IV/2000 tentang Murabahah, disebutkan "bahwa dalam rangka membantu masyarakat guna melangsungkan dan meningkatkan kesejahteraan dan berbagai kegiatan, bank syariah perlu memiliki fasilitas murabahah bagi yang memerlukannya, yaitu menjual suatu barang dengan menegaskan harga belinya kepada pembeli dan pembeli membayarnya dengan harga yang lebih sebagai laba".

Sedangkan menurut Antonio (2017:101) "murabahah adalah jual beli barang pada harga asal dengan tambahan keuntungan yang disepakati”. Murabahah merupakan menjual dengan modal asli bersama tambahan keuntungan yang jelas. Penerapan ini bank bertindak sebagai pembeli sekaligus sebagai penjual barang yang tertentu yang dibutuhkan nasabahnya.

Oleh karena pembiayaan murabahah tidak menggunakan prinsip bagi hasil, tetapi prinsip jual beli, maka keuntungan atas pembiayaan yang diberikan oleh lembaga keuangan syariah ini lazim disebut dengan keuntungan murabahah atau margin murabahah. Islahuzzaman (2012 : 259) menjelaskan istilah gross margin sebagai kelebihan penjualan dari harga pokok penjualan barang jadi atas harga pokok persediaan barang dagang yang dibeli dan dijual kembali.

Berdasarkan definisi di atas dapat disimpulkan bahwa keuntungan pembiayaan murabahah merupakan perolehan laba atau keuntungan dari hasil pembiayaan dengan akad jual beli yang diberikan kepada nasabah di mana bank memberitahu terlebih dahulu harga pokok barang dan biaya-biaya lain kepada nasabah untuk disepakati bersama, dan untuk pembayarannya dilakukan bisa dengan tunai atau dengan cara angsuran sesuai dengan jangka waktu yang telah disepakati bersama dan sesuai dengan kesanggupan dari nasabah itu sendiri.

\subsection{Pembiayaan Mudharabah dan Bagi Hasil Mudharabah}

Di dalam Fatwa Dewan Syari'ah Nasional No.: 07/DSN-MUI/IV/2000 tentang Pembiayaan Mudharabah (Qiradh), disebutkan "bahwa dalam rangka mengembangkan dan meningkatkan dana lembaga keuangan syariah (LKS), pihak LKS dapat menyalurkan dananya kepada pihak lain dengan cara mudharabah, yaitu akad kerjasama suatu usaha antara dua pihak di mana pihak pertama (malik, shahib al-mal, LKS) menyediakan seluruh modal, sedang pihak kedua ('amil, mudharib, nasabah) bertindak selaku pengelola, dan keuntungan usaha dibagi di antara mereka sesuai kesepakatan yang dituangkan dalam kontrak".

Sedangkan menurut Anshori (2018) "mudharabah adalah akad kerjasama usaha antara dua pihak dimana pihak pertama menyediakan seluruh modal, sedangkan pihak lainnya menjadi pengelola dana dalam suatu kegiatan yang produktif".

Terkait bagi hasil, Hakim (2012) mendefinisikan bahwa bagi hasil merupakan suatu karakteristik atau ciri khas yang ada dalam pelaksanaan bank syariah secara mendasar karena sesuai dengan prinsip syariat Islam yang tak mengenal bunga. Pembagian keuntungan atau bagi hasil ini dilakukan melalui tingkat perbandingan rasio, bukan ditetapkan dalam jumlah yang pasti. Sehingga dalam setiap kegiatan bank 
syariah baik dalam bentuk simpanan atau pembiayaan memiliki tingkat keuntungan bagi hasil yang berbeda.

Berdasarkan definisi di atas, dapat disimpulkan bahwa keuntungan bagi hasil pembiayaan mudharabah adalah hasil atau perolehan laba dari kontrak atau akad antara dua pihak yang mana pihak pertama berperan sebagai pemilik modal dan mempercayakan seluruh modalnya untuk dikelola oleh pihak kedua, yaitu pengelola usaha, dengan tujuan untuk mendapatkan keuntungan yang dibagi bersama sesuai dengan kesepakatan yang telah dibuat dan disetujui sebelumnya.

\subsection{Pembiayaan Musyarakah dan Bagi Hasil Musyarakah}

Di dalam Fatwa Dewan Syari'ah Nasional No.: 08/DSN-MUI/IV/2000 tentang Pembiayaan Musyarakah, disebutkan "bahwa kebutuhan masyarakat untuk meningkatkan kesejahteraan dan usaha terkadang memerlukan dana dari pihak lain, antara lain melalui pembiayaan musyarakah, yaitu pembiayaan berdasarkan akad kerjasama antara dua pihak atau lebih untuk suatu usaha tertentu, di mana masingmasing pihak memberikan kontribusi dana dengan ketentuan bahwa keuntungan dan resiko akan ditanggung bersama sesuai dengan kesepakatan". Dalam fatwa DSN-MUI tersebut disebutkan juga bahwa pembiayaan musyarakah yang memiliki keunggulan dalam kebersamaan dan keadilan, baik dalam berbagi keuntungan maupun risiko kerugian.

Harahap dan rekan (2010) menyampaikan bahwa musyarakah adalah akad kerjasama di antara para pemilik modal yang mencampurkan modal mereka untuk tujuan mencari keuntungan. Dalam musyarakah mitra dan bank sama-sama menyediakan modal untuk membiayai suatu usaha tertentu, baik yang sudah berjalan maupun yang baru. Selanjutnya mitra dapat mengembalikan modal tersebut berikut bagi hasil yang telah disepakati secara bertahap atau sekaligus kepada bank. Dikarenakan setiap mitra tidak dapat menjamin modal mitra lainnya, maka setiap mitra dapat meminta mitra lainnya untuk menyediakan jaminan atas kelalaian atau kesalahan yang disengaja.

Di dalam konsep bagi hasil yang benar, tidak hanya berbagi keuntungan saja, namun juga membagi risiko bersama. Terkait bagi hasil dalam pembiayaan musyarakah, laba dibagi di antara para mitra, baik secara proporsional sesuai dengan modal yang disetorkan (baik berupa kas maupun aktiva lainnya) atau sesuai nisbah yang disepakati oleh semua mitra. Sedangkan rugi dibebankan secara proporsional sesuai dengan modal yang disetorkan, (Harahap dan rekan, 2010). Rivai dan Arifin (2010 : 799) menyebutkan bahwa bagi hasil adalah suatu sistem pengolahan dana dalam perekonomian Islam yakni pembagian hasil usaha antara pemilik modal dan pengelola. Proses penentuan tingkat bagi hasil diperlukan kesepakatan kedua belah pihak, yang terungkap dalam nisbah bagi hasil.

\subsection{Return on Asset (ROA)}

Return on asset merupakan salah satu rasio keuangan, yang umum digunakan oleh perusahaan untuk mengevaluasi efektivitas dan efisiensi perusahaan dalam mengelola 
seluruh aktiva yang dimilikinya. Menurut Kasmir (2014 : 136) "Return on Asset merupakan rasio yang menunjukkan hasil (return) atas jumlah aktiva yang digunakan dalam perusahaan dan juga merupakan suatu ukuran tentang efektifitas manajemen dalam mengelola investasinya”. Sedangkan Munawir (2002 : 219) mendefinisikan bahwa "return on asset adalah bentuk yang merefleksikan seberapa banyak perusahaan telah memperoleh hasil atas sumber daya keuangan yang ditanamkan oleh perusahaan".

Berdasarkan definisi - definisi di atas maka dapat disimpulkan bahwa return on asset di bisnis perbankan, yaitu suatu rasio yang digunakan untuk mengukur dan melihat kemampuan perbankan dalam menghasilkan keuntungan atau laba dari pemanfaatan atau pengelolaan aktiva bank itu sendiri. Jika perolehan rasio return on asset semakin kecil, hal ini menunjukan kurang baiknya kemampuan bank dalam mengelola aktiva untuk memperoleh keuntungan.

\subsection{Kerangka Pemikiran}

Penelitian ini merupakan pengembangan dari penelitian - penelitian terdahulu yang menggunakan salah satu atau lebih variabel yang sama. Perbedaannya adalah obyek penelitian ini mengambil sampel data pembiayaan di PT Bank BRI Syariah, dan berdasarkan periode waktu data-data tahun 2014 sampai dengan 2018.

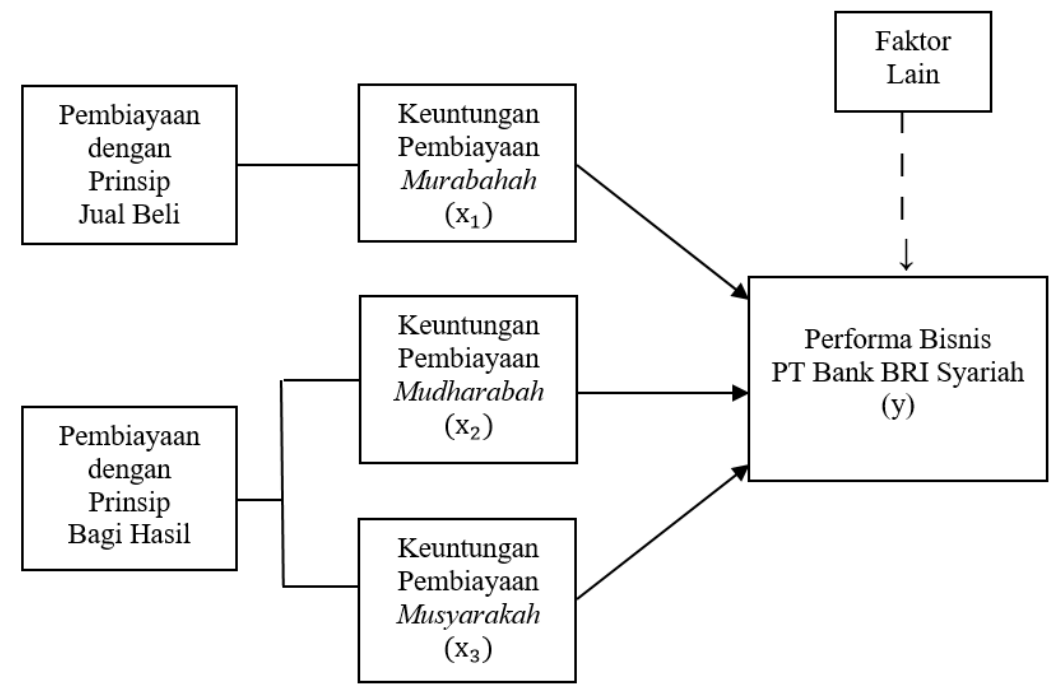

Gambar 2. Kerangka Pemikiran

\section{METODE PENELITIAN}

\subsection{Obyek Penelitian}

Objek penelitian dalam penelitian ini adalah laporan keuangan triwulan PT. Bank BRI Syariah periode tahun 2014 sampai dengan tahun 2018, yang telah dipublikasikan. Setelah mengumpulkan data, peneliti mendapatkan sampel 20 laporan keuangan triwulan. 


\subsection{Sumber dan Teknik Pengumpulan Data}

Teknik pengumpulan data yang dilakukan dalam penelitian ini adalah teknik dokumentasi yaitu teknik pengumpulan data dengan menelaah dokumentasi. Dilakukan dengan meneliti dan menganalisa laporan-laporan yang sudah dipublikasikan dan yang terdapat dalam website resmi perusahaan, serta dilakukan juga pengkajian berbagai literatur di antaranya dari buku-buku, artikel dalam jurnal, tesis, serta karya ilmiah lainnya yang berkaitan dengan masalah penelitian.

Data tentang keuntungan pembiayaan, total asset dan laba usaha yang terdapat di Laporan Keuangan diperoleh dari website resmi PT Bank BRI Syariah. Semua data tersebut kemudian diolah sesuai dengan kebutuhan penelitian.

\subsection{Metode Penelitian dan Analisis Data}

Metode penelitian yang digunakan adalah metode kuantitatif. Prosedur pengolahan data dalam penelitian ini dimulai dengan memilah dan memasukkan datadata ke dalam variabel-variabel yang digunakan dalam penelitian ini. Kemudian datadata tersebut dianalisis dengan menggunakan analisa regresi berganda data panel, dengan bantuan SPSS for windows. Antara lain uji-t untuk melihat pengaruh masingmasing pembiayaan dengan prinsip jual beli dan pembiayaan dengan prinsip bagi hasil, terhadap performa bisnis PT Bank BRI Syariah. Serta uji-F untuk melihat pengaruh keseluruhan pembiayaan dengan prinsip jual beli dan pembiayaan dengan prinsip bagi hasil (secara bersama-sama) terhadap performa bisnis PT Bank BRI Syariah.

\section{HASIL DAN PEMBAHASAN}

4.1 Pengaruh Keuntungan Pembiayaan Murabahah $\left(\mathrm{X}_{1}\right)$ terhadap Return on Asset (Y) di PT Bank BRI Syariah

\subsubsection{Analisis Koefisien Determinasi}

Analisis koefisien determinasi digunakan untuk mengetahui seberapa besar pengaruh dari keuntungan pembiayaan murabahah sebagai variabel independent terhadap Return On Asset sebagai variabel dependent, dapat dilihat pada tabel berikut:

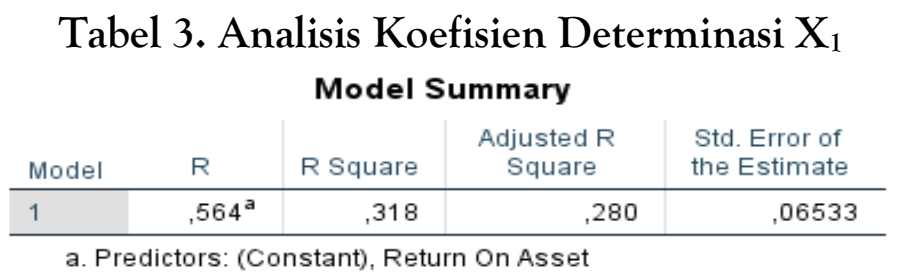

Sumber : Hasil Penelitian 2019

Pada tabel di atas, dapat dilihat bahwa nilai $\mathrm{R}$ square yang diperoleh adalah sebesar 0,318 atau $31,8 \%$. Sehingga dapat disimpulkan bahwa pengaruh keuntungan pembiayaan murabahah terhadap return on asset di PT. Bank BRI Syariah, sebesar 31,8\%. Kemudian sisanya sebesar 68,2\% diduga dipengaruhi oleh faktor lain yang tidak diteliti oleh peneliti. 


\subsubsection{Uji t}

Pengujian ini dilakukan untuk menentukan apakah variabel dependent dan variabel independent memiliki pengaruh secara parsial, dapat dilihat pada tabel berikut:

\section{Tabel 4. Uji t $\mathrm{X}_{1}$}

\section{Coefficients $^{\mathrm{a}}$}

\begin{tabular}{|c|c|c|c|c|c|c|}
\hline \multirow[b]{2}{*}{ Model } & & \multicolumn{2}{|c|}{ Unstandardized Coefficients } & \multirow{2}{*}{$\begin{array}{c}\text { Standardized } \\
\text { Coefficients } \\
\text { Beta }\end{array}$} & \multirow[b]{2}{*}{$t$} & \multirow[b]{2}{*}{ Sig. } \\
\hline & & B & Std. Error & & & \\
\hline \multirow[t]{2}{*}{1} & (Constant) & 1,950 & .448 & & 4,357 &, 000 \\
\hline & $\begin{array}{l}\text { Keuntungan Bagi Hasil } \\
\text { Murabahah }\end{array}$ & $-2,192$ &, 756 &,- 564 & $-2,899$ &, 010 \\
\hline
\end{tabular}

Sumber : Hasil Penelitian 2019

Berdasarkan tabel di atas, hasil pengujian hipotesis menunjukkan bahwa nilai $t_{\text {hitung }}$ $=-2,899<$ nilai $t_{\text {tabel }}=2,10092$. Dengan nilai sig 0,010<0,05 maka, Ho ditolak dan H1 diterima. Dengan demikian menunjukan bahwa keuntungan pembiayaan murabahah berpengaruh negatif signifikan terhadap return on asset di PT. Bank BRI Syariah.

\subsection{Pengaruh Keuntungan Pembiayaan Mudharabah $\left(\mathrm{X}_{2}\right)$ terhadap Return on Asset (Y) di PT Bank BRI Syariah}

\subsubsection{Analisis Koefisien Determinasi}

Analisis koefisien determinasi digunakan untuk mengetahui seberapa besar pengaruh dari keuntungan pembiayaan mudharabah sebagai variabel independent terhadap return on asset sebagai variabel dependent, dapat dilihat pada tabel berikut:

\section{Tabel 5. Analisis Koefisien Determinasi $\mathrm{X}_{2}$}

\begin{tabular}{ll|l|c|c}
\multicolumn{5}{c}{ Model Summary } \\
Model & $\mathrm{R}$ & R Square & $\begin{array}{c}\text { Adjusted R } \\
\text { Square }\end{array}$ & $\begin{array}{c}\text { Std. Error of } \\
\text { the Estimate }\end{array}$ \\
\hline 1 &, $239^{\mathrm{a}}$ &, 057 &, 005 &, 29854 \\
\hline \multicolumn{3}{c}{$\begin{array}{l}\text { a. Predictors: (Constant), Keuntungan Bagi Hasil } \\
\text { Mudharabah }\end{array}$}
\end{tabular}

Sumber : Hasil Penelitian 2019

Pada tabel di atas, dapat dilihat bahwa nilai R square yang diperoleh adalah sebesar 0,057 atau 5,7\%. Sehingga dapat disimpulkan bahwa pengaruh keuntungan pembiayaan mudharabah terhadap return on asset di PT. Bank BRI Syariah, sebesar $5,7 \%$. Kemudian sisanya sebesar 94,3\% diduga dipengaruhi oleh faktor lain yang tidak diteliti oleh peneliti.

\subsubsection{Uji t}

Pengujian ini dilakukan untuk menentukan apakah variabel dependent dan variabel independent memiliki pengaruh secara parsial atau secara individu, dapat dilihat pada tabel berikut: 


\begin{tabular}{|c|c|c|c|c|c|c|}
\hline \multicolumn{7}{|c|}{$\begin{array}{c}\text { Tabel 6. Uji t } \mathrm{X}_{2} \\
\text { Coefficients }^{\mathrm{a}}\end{array}$} \\
\hline \multirow[b]{2}{*}{ Model } & & \multicolumn{2}{|c|}{ Unstandardized Coefficients } & \multirow{2}{*}{$\begin{array}{c}\text { Standardized } \\
\text { Coefficients } \\
\text { Beta }\end{array}$} & \multirow[b]{2}{*}{$t$} & \multirow[b]{2}{*}{ Sig. } \\
\hline & & B & Std. Error & & & \\
\hline 1 & (Constant) & -119 &, 753 & &,- 158 & 876 \\
\hline & $\begin{array}{l}\text { Keuntungan Bagi Hasil } \\
\text { Mudharabah }\end{array}$ & 14,225 & 13,642 & .239 & 1,043 &, 311 \\
\hline
\end{tabular}

Sumber : Hasil Penelitian 2019

Berdasarkan tabel di atas, hasil pengujian hipotesis menunjukkan bahwa nilai thitung $_{\text {han }}$ $=1,043<$ nilai $t_{\text {tabel }}=2,10092$. Dengan nilai sig 0,311 >0,05 maka, Ho diterima dan H1 ditolak. Artinya keuntungan pembiayaan mudharabah tidak berpengaruh yang signifikan terhadap return on asset di PT. Bank BRI Syariah.

\subsection{Pengaruh Keuntungan Pembiayaan Musyarakah $\left(\mathrm{X}_{3}\right)$ terhadap Return on Asset \\ (Y) di PT Bank BRI Syariah}

\subsubsection{Analisis Koefisien Determinasi}

Analisis koefisien determinasi digunakan untuk mengetahui seberapa besar pengaruh dari keuntungan pembiayaan musyarakah sebagai variabel independent terhadap return on asset sebagai variabel dependent, dapat dilihat pada tabel berikut:

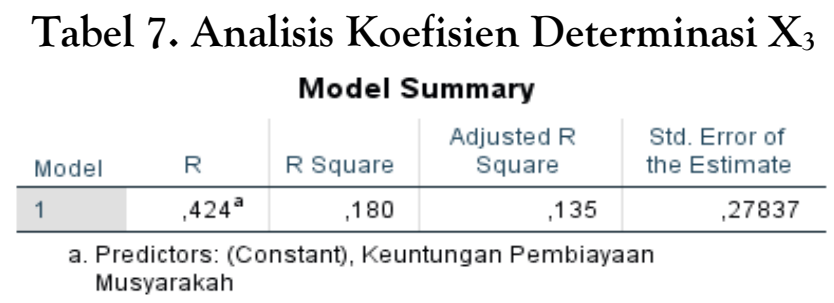

Sumber : Hasil Penelitian 2019

Pada tabel di atas, dapat dilihat bahwa nilai $\mathrm{R}$ square yang diperoleh adalah sebesar 0,180 atau 18\%. Sehingga dapat disimpulkan bahwa pengaruh keuntungan pembiayaan musyarakah terhadap return on asset di PT. Bank BRI Syariah, sebesar $18 \%$. Kemudian sisanya sebesar $82 \%$ diduga dipengaruhi oleh faktor lain yang tidak diteliti oleh peneliti.

\subsubsection{Uji t}

Pengujian ini dilakukan untuk menentukan apakah variabel dependent dan variabel independent memiliki pengaruh secara parsial atau secara individu, dapat dilihat pada tabel berikut: 
Tabel 7. Uji t $\mathrm{X}_{3}$

Coefficients $^{a}$

\begin{tabular}{|c|c|c|c|c|c|c|}
\hline \multirow[b]{2}{*}{ Model } & & \multicolumn{2}{|c|}{ Unstandardized Coefficients } & \multirow{2}{*}{$\begin{array}{c}\text { Standardized } \\
\text { Coefficients } \\
\text { Beta }\end{array}$} & \multirow[b]{2}{*}{$t$} & \multirow[b]{2}{*}{ Sig. } \\
\hline & & B & Std. Error & & & \\
\hline \multirow[t]{2}{*}{1} & (Constant) & $-2,046$ & 1,364 & & $-1,500$ &, 151 \\
\hline & $\begin{array}{l}\text { Keuntungan Pembiayaan } \\
\text { Musyarakah }\end{array}$ & 13,753 & 6,916 & .424 & 1,989 &, 062 \\
\hline
\end{tabular}

Sumber : Hasil Penelitian 2019

Berdasarkan tabel di atas, hasil pengujian hipotesis menunjukkan bahwa nilai $t_{\text {hitung }}$ $=1,989<$ nilai $t_{\text {tabel }}=2,10092$. Dengan nilai sig 0,062 >0,05 maka, Ho diterima dan H1 ditolak. Artinya keuntungan pembiayaan musyarakah berpengaruh signifikan terhadap return on asset di PT. Bank BRI Syariah.

\subsection{Pengaruh Keseluruhan Pembiayaan dengan Prinsip Jual Beli dan Pembiayaan dengan Prinsip Bagi Hasil secara Bersama-sama terhadap Return on Asset di PT Bank BRI Syariah}

\subsubsection{Analisis Korelasi Berganda}

Analisis korelasi berganda digunakan untuk mengetahui korelasi berganda dari variabel independent yaitu keuntungan pembiayaan dengan prinsip jual beli dan keuntungan pembiayaan dengan prinsip bagi hasil terhadap variabel dependent yaitu return on asset, dapat dilihat pada tabel berikut:

Tabel 8. Analisis Korelasi Berganda

\begin{tabular}{|c|c|c|c|c|}
\hline \multicolumn{5}{|c|}{ Model Summary } \\
\hline Model & $\mathrm{R}$ & R Square & $\begin{array}{c}\text { Adjusted R } \\
\text { Square }\end{array}$ & $\begin{array}{l}\text { Std. Error of } \\
\text { the Estimate }\end{array}$ \\
\hline 1 & $.726^{a}$ & .528 & .439 & .22408 \\
\hline
\end{tabular}

Sumber : Hasil Penelitian 2019

Berdasarkan tabel diatas, diketahui bahwa nilai korelasi sebesar 0,726. Artinya terdapat hubungan antara keuntungan pembiayaan dengan prinsip jual beli dan keuntungan pembiayaan dengan prinsip bagi hasil secara simultan terhadap return on asset di PT. Bank BRI Syariah.

\subsubsection{Analisis Regresi Berganda}

Analisis regresi berganda yaitu untuk mengetahui regresi berganda dari variabel independent keuntungan pembiayaan dengan prinsip jual beli dan keuntungan pembiayaan dengan prinsip bagi hasil terhadap variabel dependent yaitu return on asset, yang dilakukan oleh peneliti maka hasilnya dapat dilihat pada tabel sebagai berikut: 
Tabel 9. Analisis Regresi Berganda

\begin{tabular}{|c|c|c|c|c|c|c|}
\hline \multicolumn{7}{|c|}{ Coefficients $^{a}$} \\
\hline \multirow[b]{2}{*}{ Model } & & \multicolumn{2}{|c|}{ Unstandardized Coefficients } & \multirow{2}{*}{$\begin{array}{l}\text { Standardized } \\
\text { Coefficients } \\
\text { Beta }\end{array}$} & \multirow[b]{2}{*}{$t$} & \multirow[b]{2}{*}{ Sig. } \\
\hline & & $\mathrm{B}$ & Std. Error & & & \\
\hline \multirow[t]{4}{*}{1} & (Constant) & $-1,540$ & 1,511 & & $-1,019$ &, 323 \\
\hline & $\begin{array}{l}\text { Keuntungan Pembiayaan } \\
\text { Murabahah }\end{array}$ & $-2,026$ & .705 &,- 521 & $-2,872$ & ,011 \\
\hline & $\begin{array}{l}\text { Keuntungan Pembiayaan } \\
\text { Mudharabah }\end{array}$ & 22,808 & 10,479 & ,383 & 2,176 &, 045 \\
\hline & $\begin{array}{l}\text { Keuntungan Pembiayaan } \\
\text { Musyarakah }\end{array}$ & 10,859 & 5,913 &, 335 & 1,837 & .085 \\
\hline
\end{tabular}

Sumber : Hasil Penelitian 2019

Dari hasil analisis tersebut, diperoleh model regresi berganda sebagai berikut:

$$
Y=1,540-2,026 X_{1}+22,808 X_{2}+10,859 X_{3}
$$

Dari model diatas dapat dijelaskan, bahwa:

a. Nilai konstanta, artinya jika semua variabel bebas memiliki nilai nol (0) maka nilai return on asset sebesar 1,540 .

b. Variabel $\mathrm{X}_{1}$ terhadap $\mathrm{Y}$, nilai koefisien keuntungan pembiayaan murabahah $\left(\mathrm{X}_{1}\right)$ sebesar -2,026. Hal ini mengandung arti bahwa setiap penurunan $1 \%$ tingkat keuntungan murabahah maka return on asset (Y) akan berkurang sebesar -2,026 dengan asumsi bahwa variabel bebas yang lain dari model regresi adalah tetap.

c. Variabel $\mathrm{X}_{2}$ terhadap $\mathrm{Y}$, nilai koefisien keuntungan pembiayaan mudharabah $\left(\mathrm{X}_{2}\right)$ sebesar 22,808. Hal ini mengandung arti bahwa setiap kenaikan $1 \%$ tingkat keuntungan mudharabah maka return on asset (Y) akan naik 22,808 dengan asumsi bahwa variabel bebas yang lain dari model regresi adalah tetap.

d. Variabel $\mathrm{X}_{3}$ terhadap $\mathrm{Y}$, nilai koefisien keuntungan pembiayaan musyarakah $\left(\mathrm{X}_{3}\right)$ sebesar 10,859. Hal ini mengandung arti bahwa setiap kenaikan 1\% tingkat keuntungan musyarakah maka return on asset (Y) akan naik 10,859 dengan asumsi bahwa variabel bebas yang lain dari model regresi adalah tetap.

\subsubsection{Analisis Koefisien Determinasi}

Analisis koefisien determinasi digunakan untuk mengetahui seberapa besar pengaruh dari keuntungan pembiayaan dengan prinsip jual beli dan keuntungan pembiayaan dengan prinsip bagi hasil sebagai variabel independent terhadap return on asset sebagai variabel dependent, dapat dilihat pada tabel berikut:

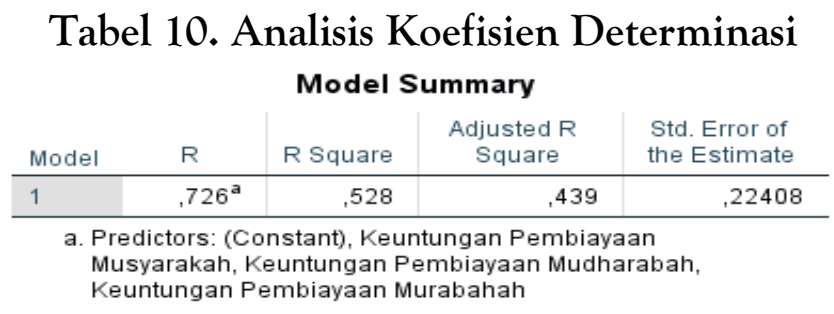

Sumber : Hasil Penelitian 2019 
Pada tabel di atas, dapat dilihat bahwa nilai $\mathrm{R}$ square yang diperoleh adalah sebesar 0,528 atau 52,8\%. Jadi disimpulkan bahwa pengaruh variabel independent yaitu keuntungan pembiayaan dengan prinsip jual beli dan keuntungan pembiayaan dengan prinsip bagi hasil secara simultan terhadap variabel dependent yaitu return on asset di PT. Bank BRI Syariah sebesar 52,8\%. Kemudian sisanya sebesar 47,2\% diduga dipengaruhi oleh faktor lain yang tidak diteliti oleh peneliti.

\subsubsection{Uji F}

Pengujian ini dilakukan untuk menentukan apakah variabel dependent dan variabel independent memiliki pengaruh secara bersama-sama atau secara simultan, dapat dilihat pada tabel berikut:

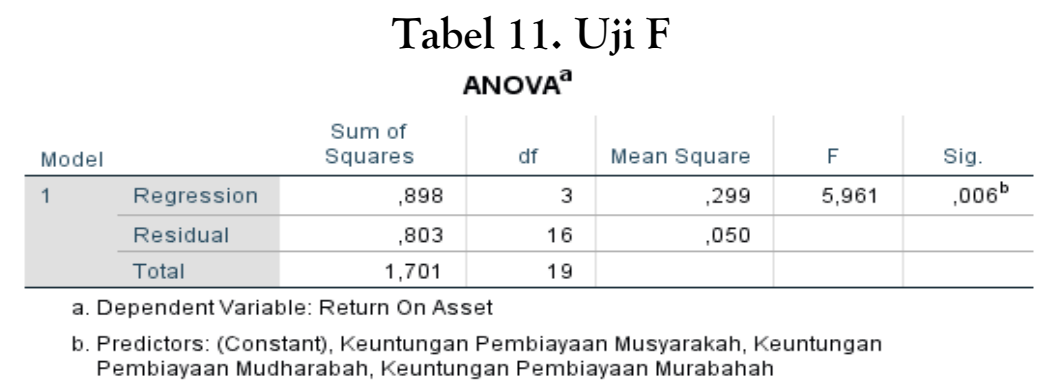

Sumber : Hasil Penelitian 2019

Berdasarkan tabel di atas menunjukkan nilai $\mathrm{F}_{\text {hitung }}=5,961>\mathrm{F}_{\text {tabel }}=3,59$ dengan tingkat signifikansi $0,006<0,05$ maka, $\mathrm{H}_{0}$ ditolak dan $\mathrm{H}_{1}$ diterima. Artinya keuntungan pembiayaan dengan prinsip jual beli dan keuntungan pembiayaan dengan prinsip bagi hasil, secara simultan berpengaruh signifikan terhadap return on asset di PT. Bank BRI Syariah.

\section{PENUTUP}

Berdasarkan hasil pengolahan data dan analisa dalam penelitian ini, maka peneliti membuat kesimpulan sebagai berikut :

1. Pengaruh keuntungan pembiayaan murabahah terhadap return on asset di PT. Bank BRI Syariah secara parsial terdapat pengaruh signifikan, dengan pengaruh sebesar 31,8\%. Hal ini dapat dilihat dalam nilai R square yang diperoleh adalah sebesar 0,318.

2. Pengaruh keuntungan pembiayaan mudharabah terhadap return on asset di PT. Bank BRI Syariah secara parsial tidak terdapat pengaruh signifikan. Hal ini dapat dilihat dari analisa perhitungan, nilai $\mathrm{R}$ square yang diperoleh hanya sebesar 0,057.

3. Pengaruh keuntungan pembiayaan musyarakah terhadap return on asset di PT. Bank BRI Syariah secara parsial terdapat pengaruh signifikan, dengan pengaruh sebesar $18 \%$. Hal ini dapat dilihat dalam nilai $\mathrm{R}$ square yang diperoleh adalah sebesar 0,180 . 
4. Pengaruh variabel independent yaitu keuntungan pembiayaan dengan prinsip jual beli dan keuntungan pembiayaan dengan prinsip bagi hasil, secara simultan terhadap variabel dependent yaitu return on asset di PT. Bank BRI Syariah terdapat pengaruh signifikan, yaitu sebesar $52,8 \%$. Sedangkan sisanya yaitu $47,2 \%$ dipengaruhi oleh faktor lain yang tidak diteliti, seperti pembiayaan dengan menggunakan akad yang lainnya dan juga keuntungan ataupun pendapatan dari operasional lainnya. Adapun dari hasil pengujian hipotesis ini dapat dilihat pada hasil uji $\mathrm{F}$ yaitu $\mathrm{F}_{\text {hitung }}=5,961>\mathrm{F}_{\text {tabel }}=3,59$ dengan tingkat signifikansi $0,006<0,05$, maka dapat disimpulkan bahwa variabel keuntungan pembiayaan dengan prinsip jual beli dan keuntungan pembiayaan dengan prinsip bagi hasil secara simultan mempengaruhi variabel return on asset secara signifikan.

\section{DAFTAR PUSTAKA}

Anshori, A. G. (2018). Perbankan Syariah Di Indonesia. Yogyakarta : Gadjah Mada University Press.

Antonio, M. S. (2005). Bank Syariah, Dari Teori ke Praktek. Jakarta : Gema Insani.

Ascarya. (2013). Akad Dan Produk Bank Syariah. Jakarta : Rajawali Pers.

Bank Indonesia. (2013). Pedoman Akuntansi Perbankan Syariah Indonesia (PAPSI) 2013. Jakarta : Bank Indonesia.

Bank Rakyat Indonesia Syariah. Laporan Publikasi Triwulanan. Jakarta: Bank Rakyat Indonesia Syariah. (http://www.brisyariah.co.id, diakses 11 November 2019).

Dewan Syariah Nasional - Majelis Ulama Indonesia. Fatwa - Fatwa DSN - MUI. (www.dsnmui.or.id, diakses 29 Oktober 2019).

Firdaus, H. R. dan Ariyanti, M . (2009). Manajemen Perkreditan Bank Umum. Bandung : Alfabeta.

Gitman, L.J. and Zutter, C.J. (2014). Principles of Managerial Finance $\left(14^{\text {th }}\right.$ edition). London : Pearson.

Haq, Rr. N. A. (2015). "Pengaruh Pembiayaan dan Efisiensi terhadap Profitabilitas Bank Umum Syariah”. Perbanas Review Volume 1, Nomor 1, November 2015, Hal. 107 -124 .

Harahap, Sofyan S., Wiroso, dan Yusuf, M. (2010). Akuntansi Perbankan Syariah. LPFEUsakti.

Ikatan Akuntan Indonesia. (2018). Standar Akuntansi Keuangan. Jakarta : Ikatan Akuntan Indonesia. (www.iaiglobal.or.id, diakses 29 Oktober 2019).

Ikatan Akuntan Indonesia. (2019). Standar Akuntansi Keuangan Syariah. Jakarta : Ikatan Akuntan Indonesia. (www.iaiglobal.or.id, diakses 29 Oktober 2019).

Islahuzzaman. (2012). Istilah-istilah Akuntansi $\mathcal{E}$ Auditing. Jakarta : Bumi Aksara.

Karim, A. (2014). Bank Islam: Analisis Fiqh dan Keuangan. Jakarta : Rajawali Press.

Muhammad. (2014). Manajemen Dana Bank Syariah. Jakarta : Rajawali Press.

Nizar, A. S. dan Anwar, M. K. (2015). "Pengaruh Pembiayaan Jual Beli, Pembiayaan Bagi Hasil, dan Intelectual Capital terhadap Kinerja Keuangan Bank Syariah”. Jurnal Akuntansi Akrual 6 (2), 2015, Hal. 127-143. 
Nurhayati, S. dan Wasilah. (2013). Akuntansi Syariah Di Indonesia, Edisi 3. Jakarta : Salemba Empat.

Purwoko, D. dan Sudiyatno, B. (2013). "Faktor-Faktor Yang Mempengaruhi Kinerja Bank (Studi Empirik Pada Industri Perbankan Di Bursa Efek Indonesia”. Jurnal Bisnis dan Ekonomi (JBE), Vol. 20, Hal. 25 - 39.

Otoritas Jasa Keuangan (OJK). (2019). Statistik Perbankan Syariah, Desember 2018. Jakarta : Otoritas Jasa Keuangan, Republik Indonesia.

Peraturan Bank Indonesia nomor 6/24/PBI/2004, tertanggal 14 Oktober 2004, tentang Bank Umum yang Melaksanakan Kegiatan Usaha Berdasarkan Prinsip Syariah. Jakarta : Bank Indonesia. (http://www.bi.go.id, diakses 25 Oktober 2019).

Rahman, A. F. dan Rochmanika, R. (2011). "Pengaruh Pembiayaan Jual Beli, Pembiayaan Bagi Hasil, dan Rasio Non Performing Financing terhadap Profitabilitas Bank Umum Syariah di Indonesia”. Jurnal Akuntansi Dan Keuangan. Vol. 2 : hal: 1-14.

Undang-Undang Nomor 10 Tahun 1998 tentang Perubahan Atas Undang-Undang Nomor 7 Tahun 1992 tentang Perbankan. Jakarta : Bank Indonesia. (http://www.bi.go.id, diakses 25 Oktober 2019).

Undang-Undang Nomor 21 Tahun 2008 Tentang Perbankan Syariah. Jakarta: Bank Indonesia. (http://www.bi.go.id, diakses 29 Oktober 2019). 